\title{
Advances Towards Integrated Biodetection Systems for Environmental Molecular Microbiology
}

\author{
Darrell P. Chandler* \\ Pacific Northwest National Laboratory, Analytical \\ Microbiology Group, 900 Battelle Blvd., PO Box 999, \\ Mail Stop P7-50, Richland WA 99352, USA
}

\begin{abstract}
To overcome many of the limitations associated with indirect detection methods, new techniques for the sensitive, specific, and direct detection of nucleic acids are required in order to accurately and quantitatively ascribe phenotype/function to uncultivated microorganisms. However, if advanced diagnostic and detection systems are going to be applied in environmental microbiology, future "biodetection" technologies and systems must be developed not from the point of view of the detector, but from the unique aspects of the environmental sample and the entire analytical process. This article highlights recent advances in nucleic acid-based technologies, and looks towards future advances that may address the broad needs and conditions imposed by environmental molecular microbiology.
\end{abstract}

\section{Introduction}

The need to rapidly detect and characterize microorganisms in environmental samples spans the technological spectrum, from fundamental microbial ecology to pathogen detection and regulatory compliance. The inability to cultivate the majority of naturally occurring microorganisms coupled with applied requirements for rapid detection has resulted in many culture-independent, molecular methods for environmental microbiology. Increasingly, detection methods emphasize nucleic acid analysis, given that DNA and RNA contains the information content distinguish between individual species (or strains) and their associated genes and activity. Nucleic acids also provide an inherent evolutionary history from which to infer taxonomical properties and/or phenotypic potential. Ultimately, it is the phenotypic reflection of molecular or microbial diversity in the environment that is the main interest of molecular ecology, and the primary driver for molecular detection methods in environmental samples. In this vein, every analytical technique has its own strengths and weaknesses that must be understood and appreciated so that accurate inferences or conclusions are drawn regarding the original sample. The thesis of this article, and a necessary requirement for future technology development in environmental molecular biology, is that the process is ultimately more important than any one

*For correspondence. Email dp.chandler@pnl.gov component or technique.

From a process perspective, then, continued reliance (and dependence) upon the polymerase chain reaction (PCR) is interesting, given the vagaries of PCR in an environmental context $(1,2)$. Notwithstanding the obvious power and utility of PCR, fundamental uncertainties surrounding the application of PCR to environmental samples have significant and mainly negative implications for the analysis of and data interpretation from microbial communities. Such techniques include denaturing gradient gel electrophoresis (DGGE; 3), single-strand conformation polymorphism (SSCP; 4), clone library screening (5), quantitative PCR $(2,6)$, differential display $(7)$ or any other technique that relies upon target amplification to faithfully assess in situ genetic diversity and/or abundance. To overcome many of the limitations associated with indirect detection methods, new techniques for the sensitive, specific, and direct detection of nucleic acids are required in order to accurately and quantitatively ascribe phenotype/ function to uncultivated microorganisms.

Biologists in general, and environmental microbiologists in particular, tend to view nucleic acids as the basis of life. Molecular technologies discussed herein, however, regard nucleic acids as analytes. From an analytical perspective, a range of non-obvious and innovative detection techniques are on the horizon that are applicable to many facets of environmental molecular microbiology. For advanced diagnostic and detection systems to be applied to environmental samples, however, future biodetection technologies and systems must be developed not from the point of view of the detector, but from the unique aspects of the environmental sample and the entire analytical process. The purpose of this article is therefore two-fold: to examine advanced molecular technologies within the context of integrated biodetection systems designed specifically for environmental samples; and introduce several new detection methods (alone) that may ultimately obviate the need for PCR in the molecular analysis of environmental samples.

\section{Integrated Biodetection Systems}

\section{Systems are More Than a Detector}

The need for integrated biodetection systems is fueled, in large part, by concerns over the use and dissemination of biological weapons, even though it is generally recognized that standard molecular methods are either too retrospective, time consuming, labor intensive or expensive to be routinely deployed in more ordinary environmental settings (8). These limitations notwithstanding, biodetection research and development is almost exclusively centered on "detection", a focus resulting in innumerable advanced detection concepts with eventual applicability to environmental samples. As outlined in Figure 1, however, 


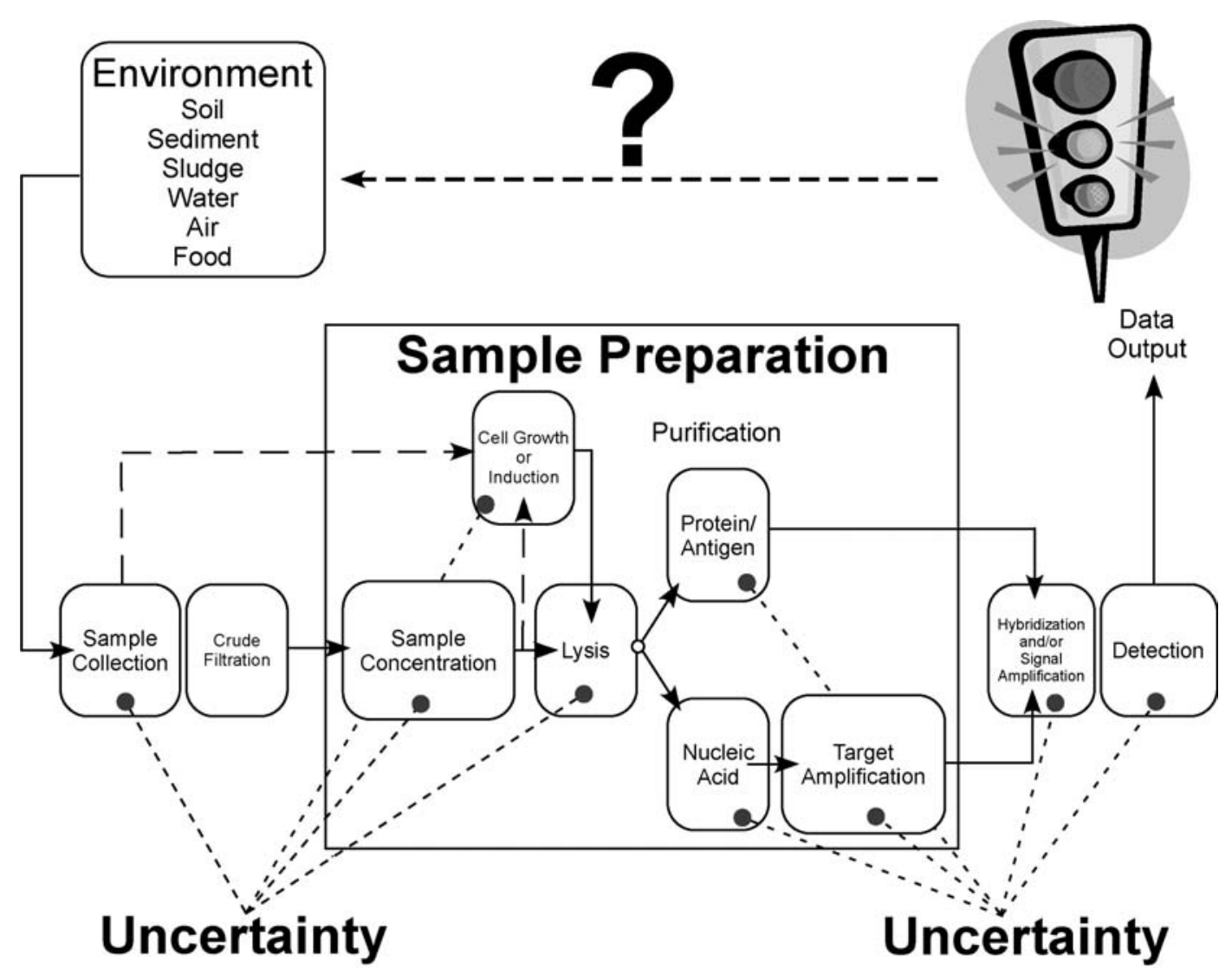

Figure 1. The biodetection process. All protein or nucleic acid detection schemes require an analytical process that can be mapped into the flow chart and functional modules shown here. Arrows represent the bio/chemistry necessary to link functional modules. Due to tremendous uncertainty associated with each of the functions, it is frequently impossible to relate the detector output (red light/green light) to the starting target concentration in the original sample.

biodetection is a process that includes sample collection, sample preparation, detection and data synthesis/output functions. The biodetection process implicitly requires different levels of technology implementation that must be seamlessly integrated in order to infer biological properties of the original sample from the data output. The technology and conceptual planes that constitute an integrated biodetection system can be considered as:

1. Hardware: The machined parts, sensors, electronics, power supply, micro-processors, communications network and control software required to implement the functions described in Figure 1;

2. Bio/chemistry: The biological sample, reagents, solutions, chemicals, biochemical process and sequencing of events, etc. required to achieve the molecular detection objective;

3. Data: The information collected from each module, sensor or device, and

4. Output: Representing the synthesis of numerous data streams into a reliable, quality, quantitative report that is unambiguously and effectively communicated to the user.
There are several intuitively obvious but frequently overlooked elements regarding Figure 1. Most importantly, it is the detection objective that defines the hardware, bio/ chemistry, data streams and data output required for an integrated biodetection system:

- What are the environmental conditions, type and size of the sample to be analyzed?

- What is the chemistry of the sample, and the properties/behavior of the organisms to be detected?

- What is their origin and distribution in the environment?

- What is the required sampling frequency, detection limit, level of specificity, and analysis speed?

- What is the frequency of allowed false positives and false negatives?

- Do we need quantitative or qualitative (yes/no) answers?

- Are the organisms alive or dead?

- What is an allowable level of operator intervention?

All of these considerations (and more) are manifest in the detection objective and must be defined to guide the appropriate selection and development of the functional modules portrayed in Figure 1 (concentration, lysis, purification, detection, output). Unfortunately for technology 
developers, the environmental sciences are so diverse and embedded in basic biological questions that it is frequently impossible to define a priori all of the technological constraints and requirements for an integrated system. Equally important, the detection objective is relative to the original sample and encompasses the entire process. It is not sufficient to assert that PCR can detect a single-copy gene without considering the upstream processes required to ensure one amplifiable copy of DNA in the PCR reaction volume. The corollary argument is that all system modules are biochemically linked; the detector is ultimately linked to the original sample through a bio/chemical process. Thus, pre-selecting a particular detector without considering the original sample conditions or sample preparation process inevitably casts significant uncertainty on the final output and analytical conclusion:

- What is the efficiency of sample collection, cell concentration or lysis?

- What is the relationship between nucleic acid copy number (DNA/RNA) and cell number as it pertains to the original sample?

- $\quad$ Are there co-purified environmental constituents that influence the efficiency of nucleic acid purification, PCR amplification, or detection?

Finally, biology is extremely variable, not only in the chemical composition and biological construction of different species (e.g. spores, Gram negative bacteria, viruses), but also in the variability of the measurement (e.g. plate counts) or analytical process (e.g. cell lysis and nucleic acid extraction efficiency):

- How is the inherent variability of each bio/chemical processes factored into the output or conclusion?

- What is the reliability, quality or confidence in the output given the uncertainty of each biochemical process?

- How does the system or technology assess, measure or quantify variability?

- How is the process-level variability affected by the type, volume or chemistry of the sample?

Clearly, understanding system-level processes and variability is key to understanding the original sample or environment, and is therefore a strict requirement for the development of integrated biodetection systems. Whether through apathy or convenience, however, it is common for scientists engaged in the analysis of environmental samples using routine molecular techniques to abandon the system-level perspective. Obviously, the extent to which data output and conclusions are impacted by the environmental sample, variability and complexity (chemical and biological), analytical process and detection objective fluctuate. Thus, it is important to recognize that technology for environmental molecular microbiology must be as flexible as the environmental systems and detection objectives are variable. The following sections therefore highlight recent, and look towards future, advances in nucleic acid technology that address the broad needs and conditions imposed by environmental molecular microbiology, following the conceptual and technological planes that are embedded in system-level analytical perspective and integrated device.

\section{Hardware}

There are two common solutions to the problems of integration and automation: robotic arms that automate common benchtop procedures (pipeting, filtration, centrifugation, mixing), or micro-total analytical systems ( $\mu$-TAS, or lab-on-a-chip devices) wherein all functions are integrated on a single chip or microfabricated structure. We are concerned here primarily with field-deployable biodetection systems that provide real-time data for unattended monitoring at the point of use and embody all functions described in Figure 1. Clearly, the convergence of electronics manufacturing techniques with analytical chemistry has resulted in revolutionary devices and approaches for DNA analysis (9-20), a trend that will continue to accelerate life sciences research and applications. Such devices typically manipulate nanoliters to femtoliters of fluid, with up to single-copy molecular detection sensitivity. The purported benefits of micro-scale molecular biology ( $\mu$-biology) are reduced analysis time and costs, and increased detection sensitivity. In most cases, the immediate applications of the technology are drug discovery and development or clinical diagnostics, not the analysis of environmental samples for microorganisms.

An idealized environmental biodetection system requires an integrated sample processing capability that delivers concentrated, purified nucleic acid to downstream gene-based detectors, with the ability to process diverse sample matrices, solution chemistries and target concentrations in a spectrum of genetic and chemical backgrounds. That is, integrated environmental biodetection systems should be capable of handling relatively high-volume nucleic acid extracts from soils, sediments, sludge, industrial process streams, undefined aqueous media, swabs and other notoriously dirty and complex sample matrices. High-volume sampling is required to ensure representative sampling and sufficient target for subsequent processing and detection. Even a cursory review of microfluidics literature illustrates that the starting point for $\mu$-device development and analyses is, in fact, pre-purified nucleic acid samples, pure cultures of easily lysed microorganisms (e.g. Escherichia coli), physiological samples (blood, urine), or solutions containing analyte at $\geq 10 \mathrm{nM}$ concentration. In these cases, sample processing (as outlined in Figure 1) is either unnecessary (e.g. PCR from whole cells) or well established.

A focus on sub-nanoliter fluidic manipulations, however, ignores the most critical aspect of many environmental situations; the need to detect microorganisms present at low concentrations in large sample volumes. For example, food safety regulations have a zero-tolerance for Salmonella, such that a biodetection device must be capable of detecting, identifying and determining the viability of one cell in $25 \mathrm{~g}$ tissue. Microbial community profiling, process monitoring, food safety, water quality assessment, and pathogen detection all reflect the need for precise and simultaneous 


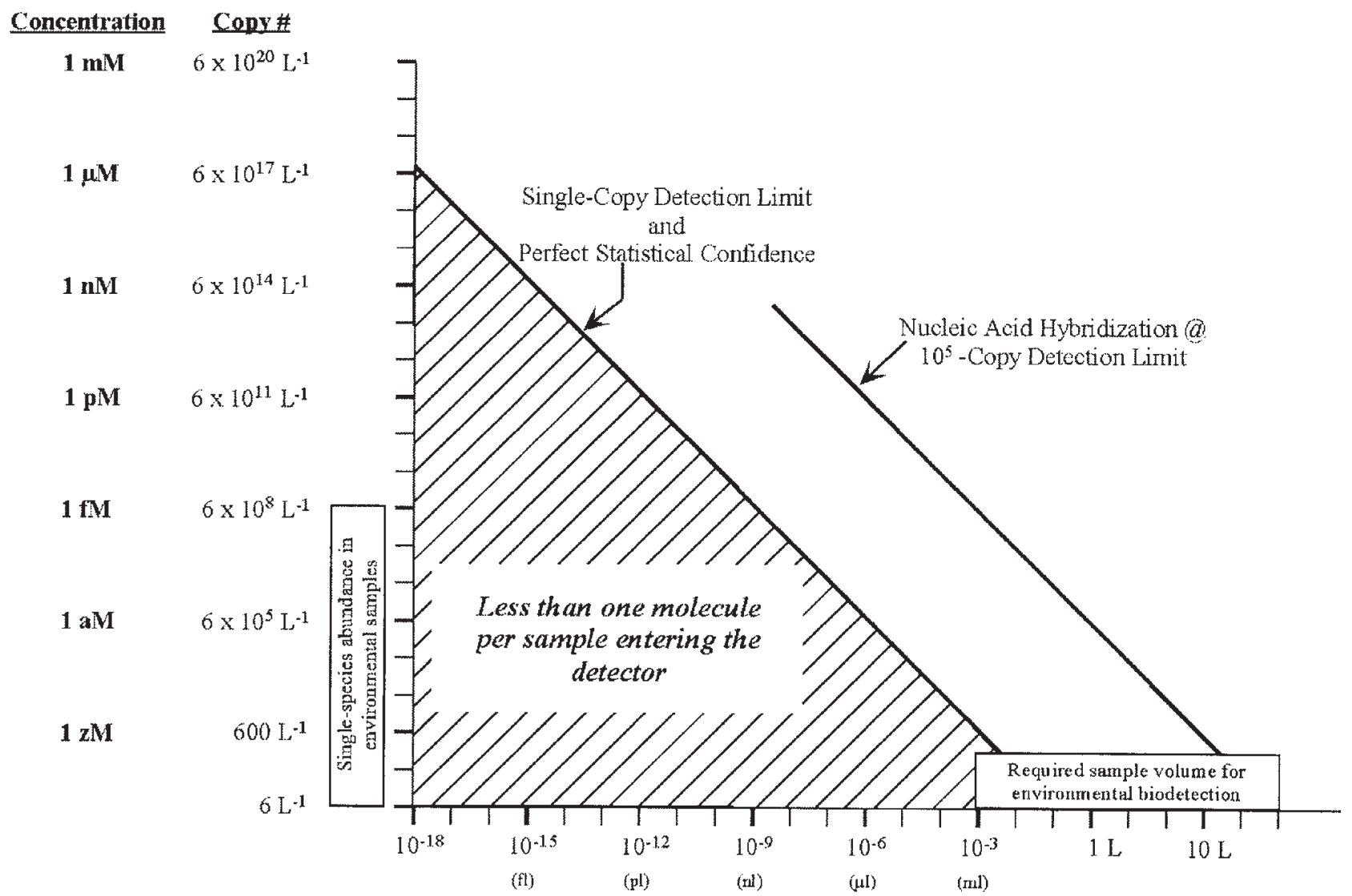

Sample Volume (liters)

Figure 2. Relationship between copy number and sample volume entering the detector, assuming perfect processing efficiency. Existing detection limits and processing inefficiencies suggest that most biodetection objectives in environmental microbiology will require sample volumes $\geq 1 \mathrm{ml}$, with many applications requiring $\geq 1$ liter of sample volume.

identification of multiple, rare organisms in large environmental samples. For perspective, detecting one copy of nucleic acid in one femtoliter is the same as detecting $10^{12}$ copies $/ \mathrm{ml}$, a single-target density greater than the total biomass of surface soils (per g), log-phase cultures of $E$. coli, or bioreactor systems! This situation is depicted in Figure 2, where target concentration is related to the sample volume entering an ideal detector. If we assume $100 \%$ processing efficiency from the point of sample collection through detection (Figure 1), the chart in Figure 2 is also a faithful representation of nucleic acid copy number required in the original sample. However, nucleic acid extraction and purification (alone) from environmental samples is an extremely inefficient process, especially for dilute (low-biomass) samples and for indigenous (non-spiked) microorganisms (21-23). Coextracted soil, sediment, sludge and wastewater constituents are also known to interfere with most common molecular techniques (24). Consequently, process inefficiencies characteristic of environmental analyses indicate that the amount of target or environmental sample volume required to make practical use of micro-analytical devices may be several orders of magnitude higher than depicted in Figure 2, and more in line with the $10^{5}$-copy detection limit typical of nucleic acid hybridization assays and ultrasensitive fluorescence detectors.

There are two other practical limitations to $\mu$-TAS from an environmental perspective. First, micron-sized features and channels run the risk of clogging or fouling by suspended particles. Second, if we assume that the environmental sample is free from suspended matter, the target concentration is 10 copies per $\mathrm{ml}$ (e.g. E. coli 0157:H7 detection in meat and poultry), and perfect detection of one molecule per nanoliter, the microfluidic device must process and concentrate $100 \mu$ to collect enough target for detection. At a typical electro-osmotic flow rate of $1 \mathrm{nl}$ per sec, the sampling process itself will require $100,000 \mathrm{sec}$ (27.8 hours). Thus, microfluidic devices are inappropriate sample acquisition/preparation platforms for many environmental applications, and are better suited for post-PCR analysis and detection as outlined in Figure 1.

The technical axioms typifying many environmental biodetection scenarios therefore require a different 
Inject, Perfuse

\section{Observation}

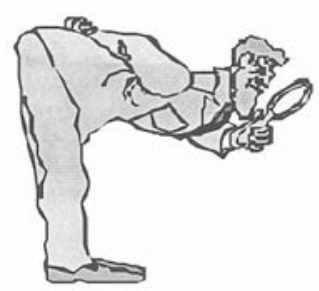

On-column or Downstream)

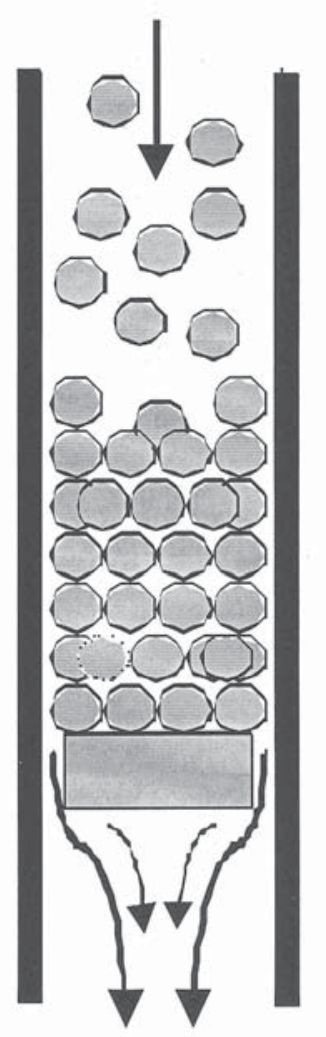

\section{Release}

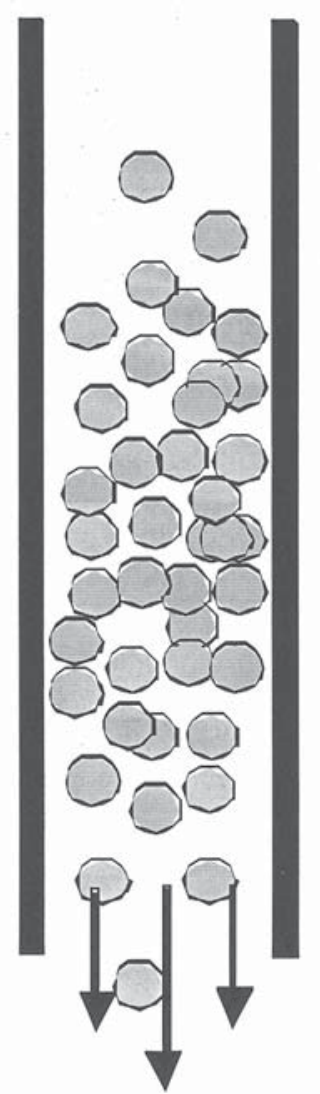

Figure 3. The renewable microcolumn concept relies upon the manipulation of microparticle suspensions in a fluidic system and retaining those particles in a suitable flow cell for sample preparation and/or detection (Inject, Perfuse). After analysis, the affinity matrix itself is removed from the system and replaced for the next sample (Release). Renewable surfaces prevent degradation, contamination or fouling of the affinity matrix, and are therefore compatible with highly specific affinity binding reagents. Direct observation of nucleic acid binding events is possible on-column, or with an appropriate downstream detector.

perspective and technological basis for automated and integrated biodetection systems that encompass the functional attributes shown in Figure 1. In particular, the environmental sample and detection objective become the overriding drivers of technology, not the hardware itself. It should be obvious from the foregoing discussion that sample processing is the limiting technology for routine deployment of $\mu$-TAS or advanced detectors in environmental molecular microbiology. To meet these requirements, we have developed a fluidics platform specifically for environmental samples that is based upon renewable surface techniques (Figure 3; reference 25), a concept arising from recent developments in analytical chemistry and instrumentation (26). The fluidic technology base specifically provides the up-front capacity, volume reduction, and sample purification capabilities necessary to span the sample ( $1 \mathrm{ml}$ to 1 liter) to detector $(\leq \mu \mathrm{l})$ volume gap discussed above, and is compatible with the functional modules depicted in Figure 1. We have already built and demonstrated the feasibility of this approach for largevolume cell concentration, cell lysis (of Bacillus spores), nucleic acid isolation and purification (from soil extracts), and PCR amplification from environmental samples, with the intention of delivering a purified, amplified (if necessary), labeled nucleic acid to any number of potential detectors. Other technological solutions to the environmental sample processing problem will undoubtedly arise as more attention is focused on the problem. Whether the biodetection hardware is based upon microfluidic, mesofluidic, or robotic manipulations, however, the hardware must ultimately be compatible with the entire biochemical process.

\section{Bio/Chemistry}

Obvious to those working in the field, but less obvious to technology developers, is that the chemistry of environmental samples is much more complex and variable than the chemistry of physiological samples or cell cultures. Humic and fulvic acids, clay and sedimentary particles, metals, radionuclides, salts and a host of other contaminants permeate the environment. Consequently, 
there is no one nucleic acid purification procedure that is effective for all sample types. Thus, a plethora of nucleic acid extraction and purification techniques and reagents exist, all of which are applicable in select applications. How can the hardware of an integrated environmental biodetection device accommodate the innumerable permutations and chemical requirements necessary to complete the entire analytical process (Figure 1)?

Molecular separations and chromatography are based upon physical (e.g. shape, size, charge) or chemical (e.g. solubility, reactivity, affinity) properties of the analyte. Practical manifestations of these separation principles are commonplace in the macro- and micro-analytical realms. Increasingly, however, biological separations are based upon interactions of the analyte (whole cells, nucleic acids, proteins) with a surface. In $\mu$-TAS, the surface is either a micromachined physical structure (27) or a self-assembled monolayer of selective chemistry (28). In macroseparations, the surface is more commonly a microparticle with tailored surface properties; virtually every major biotechnology supplier carries microparticle reagents specifically for nucleic acid separations and isolations. More common surface chemistries include non-selective (ion-exchange) or affinity (e.g. oligo-dT) functionality, with a host of chemically modified particles for user-defined modification (e.g. amine-modified or biotinylated surfaces). Microparticles come in all shapes and sizes, from soft spheres to porous structures to irregularly shaped rocks, in paramagnetic or non-magnetic varieties. Relative to the entire bio/chemical process, however, we find that microparticles are also compatible with each of the functions outlined in Figure 1: whole cell concentration $(29,30)$, cell lysis (31), nucleic acid purification (32), solidphase PCR amplification (33), and detection (34-36). This is not to say that a particle (or more generally, a reactive surface) is required to perform each of the functions involved in any particular biodetection process, only that many of the selective chemistries and functional attributes required to complete innumerable biodetection processes are compatible with microparticle-based systems and selective-chemistry.

In this context, the power, flexibility and applicability of a renewable surface system (Figure 3; ref. 32) in environmental biodetection are clear. Rather than manually manipulating each of the reagents or disposables required to perform an entire analytical process, much of the integrated bio/chemistry involved with environmental sample analyses can be accomplished with microparticle suspensions that are trapped, perfused, eluted and released within suitable mesofluidic flow cells (25). More generally, the renewable surface method allows one to consider introducing multiple, functionally distinct particles within the same fluidics platform and process, or modify the bio/chemistry and microparticles as necessary for new environmental samples and detection requirements without reconfiguring the hardware. This approach to bioseparations is a fundamental departure from the current trend in $\mu$-technology development, where devices are designed for single-purpose use, a very defined detection objective, and a relatively clean starting sample. As a result, there is an opportunity to develop free-standing, field- deployable, continuous monitoring capabilities in a range of environmental applications. Such capabilities will be extremely useful to environmental molecular microbiologists and others engaged in the detection of pathogenic microorganisms in food, air, water, soil, agricultural products or physiological fluids, and microbial community profiling in (waste)water treatment processes, reactor bioprocessing, and in situ bioremediation monitoring.

\section{Data Input and Output}

Each of the functional modules in Figure 1 has a characteristic data set or data output that provides information about, or is required to perform, the process. For example, relevant data might include measures of $\mathrm{pH}$, salinity, conductivity, density, flow velocity, turbidity, pressure, temperature or volume. Individual modules might generate complex spectra, point-source signals, or patterns with optical, electrical or magnetic readouts (for example). Strategically placed physical sensors (acoustic, pressure, etc.) can provide indirect evidence or information regarding the process (and associated efficiencies). As emphasized above, biodetection is more than a detector, and environmental microbiology is extremely variable. Hence, an integrated biodetection system must measure all of the relevant parameters that may affect the output or conclusion; datum at the point of detection in and of itself is only enough information to conclude the presence or absence of target analyte at some level in the original sample (assuming proper negative controls are built into the detector). In many cases, presence/absence is enough information to warrant action by the user. Future systems, however, are expected to be smart, and convey more (meaningful) information about the environment than simple presence/absence.

"Smart" technology means different things to different people, and is frequently discussed without a clear definition of smart. Smart technology is often associated with neural networks, cognitive controls, physical sensors, sensor arrays and terms such as embedded intelligence, silicon brains, or learned response. Within the context of this article, the definition for a smart system is one that has an inherent ability to gather information on its operating environment and history, to process that information in order to draw intelligent inferences from it, and to act on those inferences by changing its characteristics in an advantageous manner. Three features of (future) smart sensor systems, then, will be the ability to learn and adapt to changing environmental conditions, and respond accordingly. Within the context of Figure 1, however, these definitions and functions take on a slightly different meaning, one that is more problematic in biology than in physics. Namely, a smart sensor must be able to measure and deal with variability and uncertainty, yet generate an informed decision (red light/green light in Figure 1) regarding the original sample and the multitude of answers required by the detection objective. Thus, the data collection plane itself refers primarily to the collection of diverse types of data and information, whereas the data synthesis plane is the computational thought that interprets 
A.

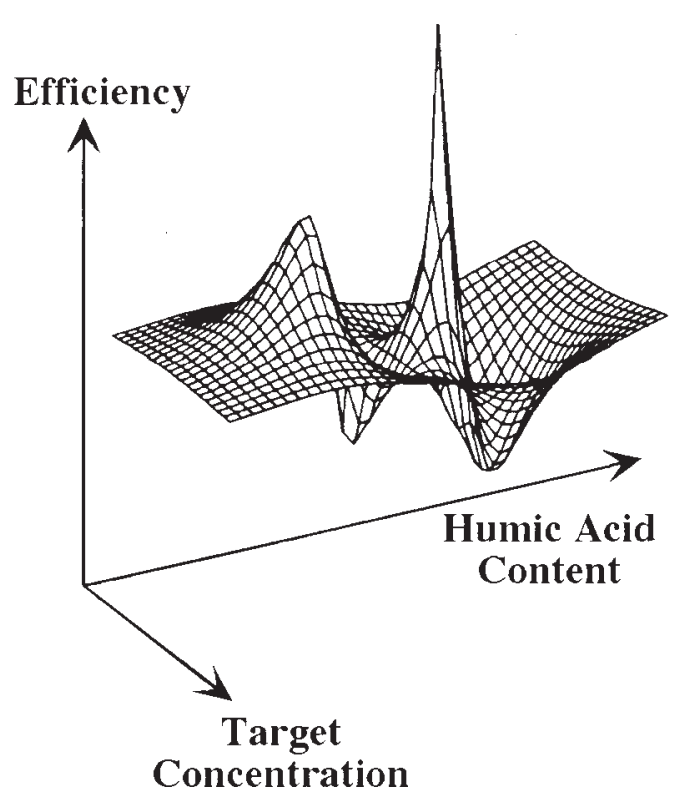

B.

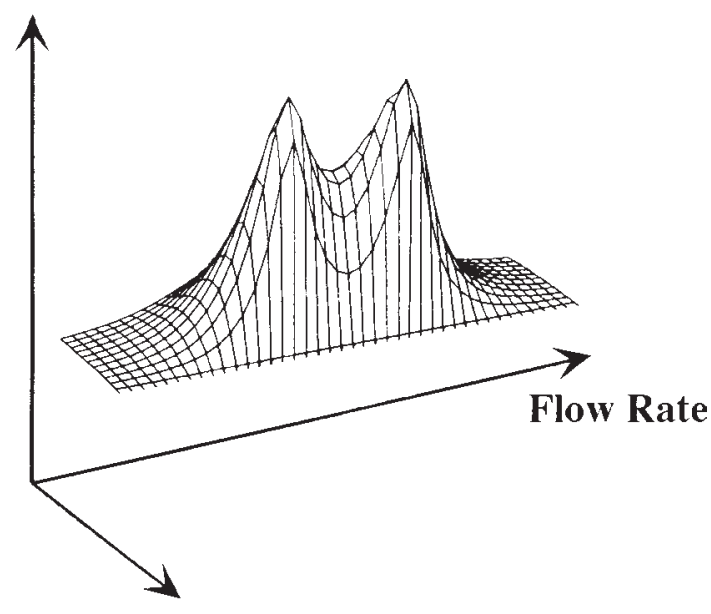

Figure 4. Hypothetical probability distributions for nucleic acid capture and purification efficiency. Panel A illustrates a distribution space relative to target concentration and humic acid content and a pre-defined purification resin. Panel B illustrates a hypothetical probability space associated with a third dimension (flow rate). Multi-dimensional probability distributions are commonplace for the bio/chemical processes illustrated in Figure 1.

the bio/chemical process and result(s).

Whereas physical properties of the environment behave according to well established laws (e.g. pV=nRT, or $\lambda=p / h$ ), environmental molecular microbiology does not; the number of relevant variables is beyond our current understanding. Intelligent biodetection could therefore represent a more quantitative data output than the simple presence/absence example or future adaptive system. In this context, the essence of the data synthesis plane is therefore to quantitatively relate the detected number of analytes to the original sample. The relationship between target numbers (in the environment) and detected analyte numbers is easily conveyed as:

$$
\mathrm{N}_{\text {Det }}=\mathrm{N}_{\mathrm{O}} \cdot f\left(\mathrm{p}_{\mathrm{c}} \cdot \mathrm{p}_{\mathrm{l}} \cdot \mathrm{p}_{\mathrm{p}} \cdot \ldots \ldots\right)
$$

where $N_{\text {Det }}$ is the number of targets measured in the detector, $\mathrm{N}_{\mathrm{O}}$ is the number of targets in the original sample, and $f()$ is some function of the efficiency of cell concentration, lysis, amplification, and/or detection steps employed in the entire process. As previously stated, the efficiency of each process is highly variable, and dependent upon multiple factors. If we simply consider the nucleic acid purification component within the context of an integrated system, for example, the efficiency may be significantly affected by target concentration (relative and absolute), purification resin (total or affinity), content of humic substances, flow rate, temperature, and a host of other variables. Figure 4 illustrates how these multiple variables result in a (multidimensional) probability distribution for $p_{p}$ (purification efficiency) that is neither absolute nor universal. In addition, each point on the probability surface has a characteristic confidence interval.
The importance of the data and data synthesis planes relative to the process, data output and detection objective is now clear. The unconditional distributions of component efficiencies and the system-level detection limit account for all environmental conditions, but these distributions can be refined by incorporating additional information about the environment, sample quality, or process. That is, realtime, indirect physical measurements and multiple sensor inputs can be used to identify the correct (range of) probability function(s) and confidence interval(s) for each bio/chemical step, and incorporate this knowledge into a more accurate and confident report. Further, incorporating probability distributions associated with sample processing components then allows one to proactively adjust and tune the process (e.g. required sample volume) according to relatively fixed limits, such as the detection limit associated with a particular detector technology.

\section{Advanced Detectors}

Fully integrated, environmental biodetection systems of the type described above are still several years away from implementation as standard research equipment or products. Nevertheless, analytical chemistry and $\mu$ technology has brought several new detection systems to the fore that have not been utilized or fully exploited in environmental settings. The systems and techniques described below were selected for discussion based upon unique analytical capabilities that may ultimately: 1) mitigate the interference of humic materials and other soluble contaminants from the detector; 2) enhance molecular biology processes or kinetics, especially at very low target concentrations in the original sample; 3) eliminate PCR 
A.

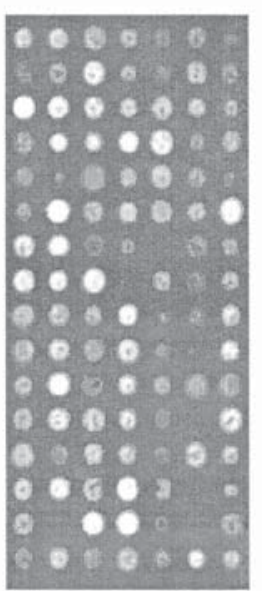

B.

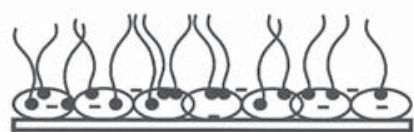

pH 8.0 Anionic surface
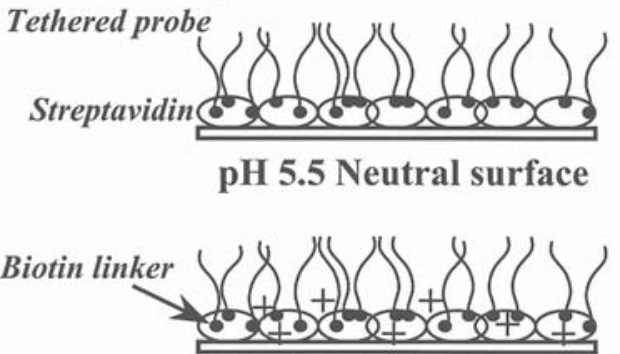

$\mathrm{pH} \leq 5.5$ Cationic surface
C.

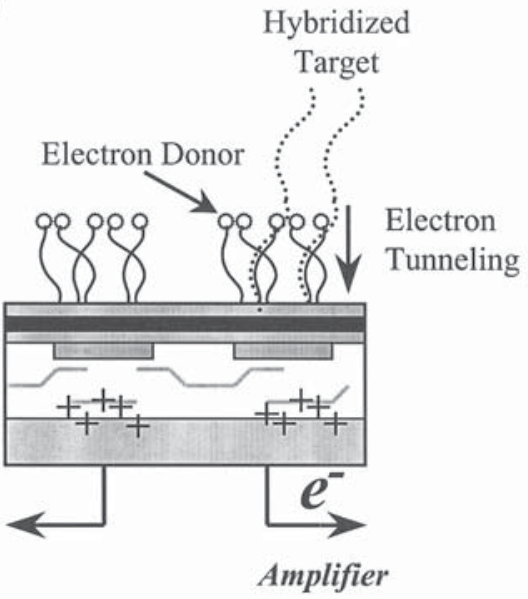

Figure 5. A) DNA microarray. Tyical spot size is $1-100 \mu \mathrm{m}$, with each spot representing a unique nucleic acid probe sequence. B) Prototypical streptavidin tunable surface. At neutral $\mathrm{pH}$, the surface is anionic. Below pH 5.5, the surface can be tuned to assume a positive charge. C) The molecular 'wire' DNA microarray. When a positive bias is applied to the electrode, nucleic acid hybrids allow electrons to migrate from an electroactive donor group, through the duplex, to the electrode. In the absence of specific DNA hybridization, no electron tunneling occurs and no signal is generated.

(and associated difficulties) from the analytical process; and 4) interface with an integrated biodetection system as outlined above.

\section{Microarrays}

Microarrays are a high-tech version of a reverse dot blot, typically containing hundreds, thousands, or hundreds of thousands of individual nucleic acid probes addressed at specific locations within a $1 \times 1 \mathrm{~cm}$ chip. Each defined location (typically $1 \mu \mathrm{m}$ to $1 \mathrm{~mm}$ in diameter) contains a different immobilized oligonucleotide, PCR product, cDNA or full-length gene (Figure 5A). Purified nucleic acid is labeled (e.g., with a fluorescent label), denatured and hybridized to the immobilized probes. After removing nonspecific DNA, the hybridization pattern is visualized with an appropriate detector. Rapid, cost-effective, and highlyspecific microarray analysis is possible because the miniaturized format allows the simultaneous hybridization and analysis of all gene or sequence targets for which specific oligonucleotides can be designed, in contrast to separate hybridizations for each gene/sequence target as in a conventional dot-blot.

Microarrays were originally developed for large-scale DNA sequencing projects, clinical diagnostics, genetic analyses, and expression profiling (37-45), but offer tremendous potential for microbial community analysis, pathogen detection and process monitoring in both basic and applied environmental science (46). Microarrays have also been adapted for ELISA-type assays $(47,48)$, including the simultaneous detection of bacteria, viruses and proteins (49). DNA, rRNA and mRNA targets can be hybridized and detected on microarrays, thereby providing a straightforward nucleic acid approach for active/inactive, live/dead discrimination in addition to species-specific identification and characterization. Internal controls, multiple probes per organism and pattern redundancy are all possible in a microarray format without significantly affecting overall analysis cost, speed or sensitivity, thus providing a level of statistical robustness to microbial detection and characterization that are not currently available by standard techniques.

Arrays are constructed on glass, poly-laminate fusions, membranes, and within gel elements, with detection formats relying upon radioactive decay, enzyme-generated chemiluminescence, fluorescence, and electron transfer. Direct PCR-labeling, sandwich assays and variations on fluorescence energy transfer are common detection schemes. Whereas single-fluor (hence, single-copy) detection is currently possible with appropriate optics (50), the current detection limit of most arrays is approximately $10^{4}-10^{5}$ hybridized copies per spot. Existing detection limits are partly driven by signal-to-noise considerations (e.g. substrate autofluorescence), but also by fundamental kinetic constraints of solid-phase or solution-phase hybridizations. That is, most array techniques (chips or gel elements) rely upon passive diffusion of targets from solution to the surface (or into a gel element), processes that are extremely inefficient and slow. In an environmental context, autofluorescence of co-purified humic acids and other contaminants also affect optical signal generation and/or readout. These limitations represent technical challenges for applied environmental applications or the analysis of low-biomass environments, especially if PCR is eliminated from the analytical process. Nevertheless, several (competing) technologies are under continued development that may surmount several of the more obvious obstacles associated with dirty samples; tunable 
surfaces, electronic sample manipulation, and molecular wires.

Recent theoretical and experimental work (51-53) indicates that 3-dimensional diffusion to a surface represents the limiting kinetic mechanism for efficient nucleic acid hybridization to an array, although steric considerations and oligonucleotide structure at the surface are also important considerations for efficient nucleic acid hybridization $(54,55)$. In contrast to $3-D$ kinetic and steric considerations, 2-dimensional movement of nonspecifically bound target nucleic acids is very rapid and can be used to enhance nucleic acid hybridization efficiency at the surface. With appropriate probe density and target size, the 2-D diffusion and hybridization properties of target nucleic acids has led to the reduction of dimensionality (RD) enhancement principle. Simply stated, restricting target nucleic acid diffusion or movement to the probe/ matrix/solution interface leads to increased hybridization efficiency and kinetics.

Active surface films directly address the RDenhancement principle, and are predicated upon observations that the rate and affinity of target DNA binding to surface probes can be greatly enhanced if the surface is coated with a chemical film that is tuned to assume a weak positive charge during hybridization, with a high negative charge during the washing step. The biotinstreptavidin linkage forms the basis of one such tunable surface (Figure $5 \mathrm{~B}$ ). At neutral $\mathrm{pH}$, streptavidin is highly anionic and provides a bulk negative surface charge, discouraging the formation of DNA duplexes at the surface. At $\mathrm{pH} \leq 5.0$, streptavidin is predominantly cationic, shielding strand-strand charge repulsion of the DNA duplexes and providing enhanced (3-D) attraction to the surface for subsequent duplex formation. Since the positive charge neutralizes strand-strand repulsive forces at the surface, low ionic strength hybridization conditions can be employed to (theoretically) reduce or eliminate secondary and tertiary structures (e.g. for rRNA) and reannealing of doublestranded target (e.g. DNA), which are competing reactions and kinetic constraints for nucleic acid hybridization on a surface. Tunable surface microarrays and ultra-low ionic strength hybridizations therefore represent a fundamentally new system for nucleic acid hybridization and detection.

Tunable surface films are a bio-chemical solution to hybridization rate enhancement. A corollary physical solution is the electrokinetic concentration principle, patented by Genometrix (56) and exploited by Nanogen (San Diego, CA) $(57,58)$. In this configuration, an electronically addressable microarray provides direct electric field control over individual probe sites, serving to effectively drive nucleic acid hybridization at a surface in the presence of a positive bias potential. More importantly, however, modulating the electric potential of individual probe sites increases the effective target concentration at the probe site. Reversing the electric field (negative bias) alters hybridization stringency and effects single-base mismatch discrimination. Similar electric field effects and manipulations have been used to isolate whole cells from blood (59) and prepare nucleic acids for on-chip hybridization (60), with forthcoming applications in antibody/ antigen and other protein-based assays. The target concentration effect is in sharp contrast to a tunable surface film, where nucleic acids are concentrated on the surface but are otherwise freely distributed over the 2-dimensional surface space. For lower-biomass environmental samples and those instances where we endeavor to avoid PCR amplification, the ability to effectively concentrate dilute targets within $\mathrm{a} \leq 100 \mu \mathrm{m}$ probe site is conceptually more pleasing and advantageous than passive hybridization techniques.

Most microarray systems are based upon fluorescence detection and optics which, as mentioned previously, are susceptible to interference by humic acids and other soluble environmental constituents. The most obvious solution to fluorescence quenching or interference is to use non-optical signal transduction systems. Clinical Micro Sensors (Pasadena, CA; now owned by Motorola) has adopted a microarray strategy based on molecular wires, utilizing the property of electron transfer through DNA duplexes $(61,62)$. Figure 5C illustrates the operating principle; probes are synthesized with a terminal, redox-active moiety and attached to an electrode surface. After target hybridization, a positive potential is applied to the electrode. At those sites where DNA hybridization has occurred, the redoxactive moiety "gives up" an electron, which tunnels through the duplex and is collected/counted at the electrode. In the absence of specific hybridization, the electron is unable to migrate from the label to the electrode and no signal is generated. Other types of molecular wires are also under development, wherein naturally conductive polymers are functionalized with a nucleic acid recognition element. The conceptual and practical advantage of these detection systems for environmental applications is that sensitive and specific measurements of DNA duplex formation is possible even in a very complex or dirty environment.

\section{Electrochemistry}

Electrochemiluminescence (ECL) is a hybrid technique that uses an electronic stimulus to generate a fluorescent signal in response to analyte binding at a surface. ECL methods have been used to detect nucleic acid $(36,63)$ and antibodybased (34) binding events, and to detect spores in soil (64). Immunoelectrochemical (IEC) detection employs antibody-antigen recognition elements, alkaline phosphatase (or other) enzymatic signal generation systems, and electrochemical substrates to generate free electrons during substrate catalysis. IEC has likewise been applied to environmental microbiology problems, such as the specific detection of pathogenic E. coli in foods (65). Both techniques rely upon passive hybridization to a surface, but avoid the problems of autofluorescence or fluorescence quenching in complex sample matrices.

The concepts of electrokinetic concentration and electrochemical detection coalesce in analytical techniques such as adsorptive potentiometric stripping analysis (PSA) and cyclic voltammetry. PSA and cyclic voltammetry can quantify DNA or RNA at $1.0-2.5 \mathrm{pg} / \mu \mathrm{l}$ utilizing carbon paste or graphite electrodes (66-69), detection sensitivities almost on par with fluorescent methods (in an environmental context). Highly sensitive electrochemical measurements are possible because DNA is accumulated 
at the electrode prior to the electrochemical measurement, a mass action principle not possible with passive adsorption methods. Both PSA and cyclic voltammetry are amenable to indicator-free operation, whereby an intrinsic property of the nucleic acid target is utilized to generate an electrical signal. For example, multiple and distinct electrochemical signatures can be generated from guanine $(G)$ oxidation $(66,70)$ or combined cytosine/adenine $(\mathrm{C} / \mathrm{A})$ reduction $(70,71)$. Redox manipulation of intercalator labels is also commonplace (67). An intriguing aspect of electrochemical techniques is that each signature is unique; $G$ oxidation, for example, generates a characteristic aniodic peak at $+1.05 \mathrm{~V}$ versus a $\mathrm{Ag} / \mathrm{AgCl}$ reference electrode. These combined attributes of electrochemical DNA detection suggest that the presence of co-extracted environmental constituents can be more readily circumvented to obtain a precise and sensitive nucleic acid measurement in environmental samples. However, reliable electrochemical measurements in complex matrices are frequently complicated by electrode fouling, which may affect sensor sensitivity, accuracy and lifetime.

\section{Other Analytical Techniques}

There are numerous other technologies with the potential to detect specific nucleic acid targets derived from environmental matrices or enhance the performance of aforementioned methods. For example, nucleic acid analogues (see references $72-74$ ) with chemically modified backbones and novel electrostatic properties might overcome some of the humic acid inhibition, thermodynamic, and kinetic limitations of current nucleic acid hybridization and detection techniques. Extremely rapid analysis of individual cells with fluorescence activated cell sorting instruments is commonplace. Similar instrumentation with lasers, photon counters, and sophisticated electronics can detect single genes in unamplified genomic DNA (50). While sensitivities are currently poor compared to fluorescence methods, ever more powerful mass spectrometry techniques are being rapidly developed and applied specifically for the direct detection, sequencing, and identification of nucleic acids and whole microbial cells (75-78). Electrospray ionization mass spectrometry, in particular, can be fluidically linked to upstream microfluidic sample processing components (79), or integrated systems of the type described earlier. Other analytical detectors include microfabricated and/or fully automated PCR instrumentation (80-84), capillary electrophoresis devices $(14,85)$, optical biosensors (86$88)$, surface plasmon devices $(89,90)$ and a host of other on-chip configurations (10-12,17,20,91). Magnetoresistance and atomic force principles are also under development for nucleic acid detection and biosensor applications (92-94).

There is clearly a milieu of analytical systems, detectors and micromachined devices with potential applications in environmental molecular microbiology. While most of the technologies described in this section are advancing analyte detection limits, they still require a tremendous amount of sample processing before detection occurs and are not themselves developed within the context of an integrated system. In many cases, sample processing also includes or requires PCR amplification, a significant hindrance to fully integrated, smart biodetection systems for environmental analyses, as described above.

\section{Concluding Remarks}

Within the far-reaching realm of biodetection, virtually every user desires the hypothetical Tricorder, popularized in the science fiction television series Star Trek, but fails to define the performance specifications for such a device. Hence, technology developers focus almost exclusively on the detector, without regard to the entire analytical process or the relationship between how a sample must be processed in order for the detector to meet the stated detection objective, and what manipulations can be accomplished with a given sample. The fundamental disconnect between advanced molecular technologies and environmental molecular microbiology is not entirely surprising; there is relatively little (financial) incentive to invest in devices or processes focused on the analysis of environmental samples. Instead, biodetection technology is developed primarily for clinical diagnostics and drug discovery. The difference in analytical perspective, however- i.e. from the point of view of the sample or detector-, is a very subtle yet fundamental aspect of future technology development for environmental biodetection. Closer inspection of advanced detector technologies alone reveals many fundamental flaws when considered from the perspective of the (environmental) sample and processing requirements (Figure 1). This article therefore emphasized the entire analytical process and its holistic relationship to technology development, with a focus on environmental variability, large sample volumes, dilute target concentrations, fluidic systems, and complex or dirty samples.

The convergence of analytical chemistry, electronics, micromachining, physics and biology is revolutionizing the way in which we look at (and for) biological elements, a trend that will continue well into the foreseeable future. When we consider the fictional Tricorder, a sensor that can detect and report on a DNA point mutation from 30 meters away while simultaneously recording all life signs and physical parameters associated with the object, we must eventually begin to think of bio-sensing in entirely different terms. That is, molecular biology is an inherently fluidic process as we currently practice the art, yet the hypothetical Tricorder never samples a fluid or tissue directly. The holistic biodetection framework described here therefore represents a necessary but relatively limited technology base for future biodetection devices. To transition the Tricorder from science fiction to science fact will ultimately require another molecular and $\mu$-technology revolution, one in which precise biological properties are inferred from noninvasive physical or chemical attributes. Nobody knows from where these technologies will arise, but it is clear that technology development requires a multidisciplinary effort. It is also clear that for advanced technologies to be adapted and developed specifically for environmental microbiology, it will be necessary for environmental molecular biologists to wander the hallways of Physics and Chemistry departments, and take a more proactive stance towards 
Technology Development to address the unique aspects of environmental samples and biodetection problems.

\section{Acknowledgements}

This work was supported by the U.S. Department of Energy (DOE) under the Assessment element of the Natural and Accelerated Bioremediation (NABIR) program. Pacific Northwest National Laboratory is operated for the U.S. DOE by Battelle Memorial Institute under contract DE-AC0676RLO 1830.

\section{References}

1. Wintzingerode, F.v., Göbel, U.B. and Stackebrandt, E. 1997. Determination of microbial diversity in environmental samples: pitfalls of PCR-based rRNA analysis. FEMS Microbiol. Rev. 21: 213-229.

2. Chandler, D.P. 1998. Redefining relativity: quantitative PCR at low template concentrations for industrial and environmental microbiology. J. Ind. Microbiol. 21: 128140.

3. Muyzer, G., De Waal, E.C. and Uitterlinden, A.G. 1993. Profiling of complex microbial populations by denaturing gradient gel electrophoresis analysis of polymerase chain reaction-amplified genes coding for 16S rRNA. Appl. Environ. Microbiol. 59: 695-700.

4. Schwieger, F. and Tebbe, C.C. 1998. A new approach to utilize PCR-single-strand-conformation polymorphism for $16 S$ rRNA gene-based microbial community analysis. Appl. Environ. Microbiol. 64: 4870-4876.

5. Chandler, D.P., Brockman, F.J. and Fredrickson, J.K. 1997. Effect of PCR template concentration on the composition and distribution of total community $16 \mathrm{~S}$ rDNA clone libraries. Mol. Ecol. 6 475-482.

6. Halford, W.P., Falco, V.C., Gebhardt, B.M. and Carr, D.J.J. 1999. The inherent quantitative capacity of the reverse transcription-polymerase chain reaction. Anal. Biochem. 266: 181-191.

7. Fleming, J.T., Yao, W.-H. and Sayler, G.S. 1998. Optimization of differential display of prokaryotic mRNA: application to pure cultures and soil microorganisms. Appl. Environ. Microbiol. 64: 36983706.

8. Brockman, F.J. 1995. Nucleic acid-based methods for monitoring the performance of in situ bioremediation. Mol. Ecol. 4: 567-578.

9. Burns, M.A. et al. 1998. An integrated nanoliter DNA analysis device. Science. 282: 484-487.

10. Waters, L.C., Jacobson, S.C., Kroutchinina, N., Khandurina, J., Foote, R.S. and Ramsey, J.M. 1998. Microchip device for cell lysis, multiplex PCR amplification, and electrophoretic sizing. Anal. Chem. 70: 158-162.

11. Raymond, D.E., Manz, A. and Widmer, H.M. 1994. Continuous sample pretreatment using a free-flow electrophoresis device integrated onto a silicon chip. Anal. Chem. 66: 2858-2865.

12. Harrison, D.J. and Chiem, N. 1996. Immunoassay flow systems on-chip. In: Solid-State Sensor and Actuator
Workshop, Hilton Head, SC.

13. Raymond, D.E., Manz, A. and Widmer, H.M. 1996. Continuous separation of high molecular weight compounds using a microliter volume free-flow electrophoresis microstructure. Anal. Chem. 68: 25152522.

14. Woolley, A.T., Lao, K., Glazer, A.N. and Mathies, R.A. 1998. Capillary electrophoresis chips with integrated electrochemical detection. Anal. Chem. 70: 684-688.

15. Wilding, P., Pfahler, J., Bau, H.H., Zemel, J.N. and Kricka, L.J. 1994. Manipulation and flow of biological fluids in straight channels micromachined in silicon. Clin. Chem. 40: 43-47.

16. Ehrlich, D.J. and Matsudaira, P. 1999. Microfluidic devices for DNA analysis. Trends Biotechnol. 17: 315319.

17. Regnier, F.E., He, B., Lin, S. and Busse, J. 1999. Chromatography and electrophoresis on chips: critical elements of future integrated, microfluidic analytical systems for life science. Trends Biotechnol. 17: 101106.

18. Yang, J., Huang, Y., Wang, X.-B., Becker, F.F. and Gascoyne, P.R.C. 1999. Cell separation on microfabricated electrodes using dielectrophoretic/ gravitational field-flow fractionation. Anal. Chem. 71: 911-918.

19. Schmalzing, D., Koutny, L., Adourian, A., Belgrader, P., Matsudaira, P. and Ehrlich, D. 1997. DNA typing in thirty seconds with a microfabricated device. Proc. Natl. Acad. Sci. USA. 94: 10273-10278.

20. Li, P.C.H. and Harrison, D.J. 1997. Transport, manipulation, and reaction of biological cells on-chip using electrokinetic effects. Anal. Chem. 69: 15641568.

21. Steffan, R.J., Goksoyr, J., Bej, A.K. and Atlas, R.M. 1988. Recovery of DNA from soils and sediments. Appl. Environ. Microbiol. 54: 2908-2915.

22. Ogram, A., Sun, W., Brockman, F.J. and Fredrickson, J.K. 1995. Isolation and characterization of RNA from low-biomass deep-subsurface sediments. Appl. Environ. Microbiol. 61: 763-768.

23. Chandler, D.P. and Brockman, F.J. 1996. Estimating biodegradative gene numbers at a JP-5 contaminated site using PCR. Appl. Biochem. Biotechnol. 57/58: 971-982.

24. Tebbe, C.C. and Vahjen, W. 1993. Interference of humic acids and DNA extracted directly from soil in detection and transformation of recombinant DNA from bacteria and yeast. Appl. Environ. Microbiol. 59: 26572665.

25. Chandler, D.P., Holman, D.A., Brockman, F.J., Grate, J.W. and Bruckner-Lea, C.J. 2000. Renewable microcolumns for solid-phase nucleic acid separations and analysis from environmental samples. Trends Anal. Chem. 19: 314-321.

26. Ruzicka, J., Pollema, C.H. and Scudder, K.M. 1993. Jet ring cell: a tool for flow injection spectroscopy and microscopy on a renewable solid support. Anal. Chem 65: 3566-3570.

27. He, B. and Regnier, F. 1999. Microfabricated filters for microfluidic analytical systems. Anal. Chem. 71: 1464- 
1468.

28. Delamarche, E., Bernard, A., Schmid, H., Michel, B. and Biebuyck, H. 1997. Patterned delivery of immunoglobulins to surfaces using microfluidic networks. Science. 276: 779-781.

29. Di Giovanni, G.D., Hashemi, F.H., Shaw, N.J., Abrams, F.A., LeChevallier, M.W. and Abbaszadegan, M. 1999. Detection of infectious Cryptosporidium parvum oocysts in surface and filter backwash water samples by immunomagnetic separation and integrated cell culture-PCR. Appl. Environ. Microbiol. 65: 3427-3432.

30. Berry, E.D. and Siragusa, G.R. 1997. Hydroxyapatite adherence as a means to concentrate bacteria. Appl. Environ. Microbiol. 63: 4069-4074.

31. More', M.I., Herrick, J.B., Silva, M.C., Ghiorse, W.C. and Madsen, E.L. 1994. Quantitative cell lysis of indigenous microorganisms and rapid extraction of microbial DNA from sediment. Appl. Environ. Microbiol. 60: 1572-1580.

32. Chandler, D.P., Schuck, B.L., Brockman, F.J. and Bruckner-Lea, C.J. 1999. Automated nucleic acid isolation and purification from soil extracts using renewable affinity microcolumns in a sequential injection system. Talanta. 49: 969-983.

33. Toranzos, G.A. and Alvarez, A.J. 1992. Solid-phase polymerase chain reaction: applications for direct detection of enteric pathogens in waters. Can. J. Microbiol. 38: 365-369.

34. Yu, H. 1998 Comparative studies of magnetic particlebased solid phase fluorogenic and electrochemiluminescent immunoassay. J. Immunol. Meth. 218: 1-8.

35. Seo, K.H., Brackett, R.E., Frank, J.F. and Hilliard, S. 1998. Immunomagnetic separation and flow cytometry for rapid detection of Escherichia coli O157:H7. J. Food Protect. 61: 812-816.

36. DiCesare, J., Grossman, B., Katz, E., Picozza, E., Ragusa, R. and Woudenberg, T. 1993. A highsensitivity electrochemiluminescence-based detection system for automated PCR product quantitation. BioTechniques. 15: 152-157.

37. Guo, Z.G., Guilfoyle, A., Thiel, A.J., Wang, R. and Smith, L.M. 1994. Direct fluorescence analysis of genetic polymorphisms by hybridization with oligonucleotide arrays on glass supports. Nucl. Acids Res. 22: 5456-5465.

38. Lockhart, D.J. et al. 1996. Expression monitoring by hybridization to high-density oligonucleotide arrays. Nature Biotechnol. 14: 1675-1680.

39. Pease, A.C., Solas, D., Sullivan, E.J., Cronin, M.T., Holmes, C.P. and Fodor, S.P.A. 1994. Light-generated oligonucleotide arrays for rapid DNA sequence analysis. Proc. Natl. Acad. Sci. USA. 91: 5022-5026.

40. Southern, E.M., Maskos, U. and Elder, J.K. 1992. Analyzing and comparing nucleic acid sequences by hybridization to arrays of oligonucleotides: evaluation using experimental models. Genomics. 13: 10081017.

41. Yershov, G. et al. 1996. DNA analysis and diagnostics on oligonucleotide microchips. Proc. Natl. Acad. Sci. USA. 93: 4913-4918.
42. Debouck, C. and Goodfellow, P.N. 1999. DNA microarrays in drug discovery and development. Nature Genetics. 21: 48-50.

43. Hacia, J.G. 1999. Resequencing and mutational analysis using oligonucleotide microarrays. Nature Genetics 21: 42-47.

44. Lipshutz, R.J., Fodor, S.P.A., Gingeras, T.R. and Lockhart, D.J. 1999. High density synthetic oligonucleotide arrays. Nature Genetics. 21: 20-24.

45. Marshall, A. and Hodgson, J. 1998. DNA chips: an array of possibilities. Nature Biotechnology. 16: 2731.

46. Guschin, D.Y., Mobarry, B.K., Proudnikov, D., Stahl, D.A., Rittmann, B.E. and Mirzabekov, A.D. 1997. Oligonucleotide microchips as genosensors for determinative and environmental studies in microbiology. Appl. Environ. Microbiol. 63: 2397-2402.

47. Mendoza, L.G., Mcuary, P., Mongan, A., Gangadharan, R., Brignac, S. and Eggers, M. 1999. High-throughput microarray-based enzyme-linked immunosorbent assay ELISA. BioTechniques 27: 778-788.

48. Lueking, A., Horn, M., Eickhoff, H., Bussow, K., Lehrach, H. and Walter, G. 1999. Protein microarrays for gene expression and antibody screening. Anal. Biochem. 270: 103-111.

49. Rowe, C.A., Tender, L.M., Feldstein, M.J., Golden, J.P., Scruggs, S.B., MacCraith, B.D., Cras, J.J. and Ligler, F.S. 1999. Array biosensor for simultaneous identification of bacterial, viral, and protein analytes. Anal. Biochem. 71: 3846-3852.

50. Castro, A. and Williams, J.G.K. 1997. Single-molecule detection of specific nucleic acid sequences in unamplified genomic DNA. Anal. Chem. 69: 39153920.

51. Ganachaud, F., Elaïssari, A., Pichot, C., Laayoun, A. and Cros, P. 1997. Adsorption of single-stranded DNA fragments onto cationic aminated latex particles. Langmuir. 13: 701-101.

52. Chan, V., Graves, D.J. and McKenzie, S.E. 1995. The biophysics of DNA hybridization with immobilized oligonucleotide probes. Biophysical J. 69: 2243-2255.

53. Chan, V., Graves, D.J., Fortina, P. and McKenzie, S.E. 1997. Adsorption and surface diffusion of DNA oligonucleotides at liquid/solid interfaces. Langmuir. 13: 320-329.

54. Shchepinov, M.S., Case-Green, S.C. and Southern, E.M. 1997. Steric factors influencing hybridisation of nucleic acids to oligonucleotide arrays. Nucl. Acids Res. 25: 1155-1161.

55. Day, P.J.R., Flora, P.S., Fox, J.E. and Walker, M.R. 1991. Immobilization of polynucleotides on magnetic particles. Biochem. J. 278: 735-740.

56. Eggers, M.D., Hogan, M.E., Beattie, K.L., Shumaker, J., Ehrlich, D.J. and Hollis, M. 1996. Multi-site detection apparatus. Houston Advanced Research Center, Patent No. 5,532,128.

57. Sosnowski, R.G., Tu, E., Butler, W.F., O'Connell, J.P. and Heller, M.J. 1997. Rapid determination of single base mismatch mutations in DNA hybrids by direct electric field control. Proc. Natl. Acad. Sci. USA .94: 1119-1123. 
58. Edman, C.F., Raymond, D.E., Wu, D.J., Tu, E., Sosnowski, R.G., Butler, W.F., Nerenberg, M. and Heller, M.J. 1997. Electric field directed nucleic acid hybridization on microchips. Nucl. Acids Res. 25: 4907-4914.

59. Cheng, J., Sheldon, E.L., Wu, L., Heller, M.J. and O'Connell, J.P. 1998. Isolation of cultured cervical carcinoma cells mixed with peripheral blood cells on a bioelectronic chip. Anal. Chem. 70: 2321-2326.

60. Cheng, J., Sheldon, E.L., Wu, L., Uribe, A., Gerrue, L.O., Carrino, J., Heller, M.J. and O'Connell, J.P. 1998. Preparation and hybridization analysis of DNA/RNA from E. coli on microfabricated bioelectronic chips. Nature Biotechnol. 16: 541-546.

61. Wilson, E.K. 1998. Instant DNA detection. Chem. Eng. News. 76: 47-49.

62. Meade, T.J., Kayyem, J.F. and Fraser, S.E. 1997. Nucleic acid mediated electron transfer. California Institute of Technology, Patent No. 5,591,578.

63. Kenten, J.H., Gudibande, S., Link, J., Willey, J.J., Curfman, B., Major, E.O. and Massey, R.J. 1992. Improved electrochemiluminescent label for DNA probe assays: rapid quantitative assays of HIV-1 polymerase chain reaction products. Clin. Chem. 38:, 873-879.

64. Bruno, J.G. and Yu, H. 1996. Immunomagneticelectrochemiluminescent detection of Bacillus anthracis spores in soil matrices. Appl. Environ. Microbiol. 62: 3474-3476.

65. Brewster, J.D. and Mazenko, R.S. 1998. Filtration capture and immunoelectrochemical detection for rapid assay of Escherichia coliO157:H7. J. Immunol. Meth. 211: 1-8.

66. Wang, J., Cai, X., Jonsson, C. and Balakrishnan, M. 1996. Adsorptive stripping potentiometry of DNA at electrochemically pretreated carbon paste electrodes. Electroanalysis. 8: 20-24.

67. Liu, S.H., Ye, J.N., He, P.G. and Fang, Y.H. 1996. Voltammetric determination of sequence-specific DNA by electroactive intercalator on graphite electrode. Anal. Chimica Act.a 335: 239-243.

68. Mikkelsen, S.R. 1996. Electrochemical biosensors for DNA sequence detection. Electroanalysis. 8: 15-19.

69. Palecek, E. and Fojta, M. 1994. Differential pulse voltammetric determination of RNA at the picomole level in the presence of DNA and nucleic acid components. Anal. Chem. 66: 1566-1571.

70. Palecek, E. 1996. From polarography of DNA to microanalysis with nucleic acid-modified electrodes. Electroanalysis. 8: 7-14.

71. Wang, J., Grant, D.H., Ozsoz, M., Cai, X.H., Tian, B.M. and Fernandes, J.R. 1997. Adsorptive potentiometric stripping analysis of nucleic acids at mercury electrodes. Anal. Chim. Acta. 349: 77-83.

72. Egholm, M. 1993. PNA hybridizes to complementary oligonucleotides obeying the Watson-Crick hydrogen bonding rules. Nature. 365: 566-568.

73. Iyer, M., Norton, J.C. and Corey, D.R. 1995. Accelerated hybridization of oligonucleotides to duplex DNA. J. Biol. Chem. 270: 14712-14717.

74. Peffer, H.J., Hanvey, J.C., Bisi, J.E., Thomson, S.A.,
Hassman, C.F., Noble, S.A. and Babiss, L.E. 1993. Strand-invasion of duplex DNA by peptide nucleic acid oligomers. Proc. Natl. Acad. Sci. USA. 90: 1064810652.

75. Doktycz, M.Z. et al. 1995. Analysis of polymerase chain reaction-amplified DNA products by mass spectrometry using matrix-assisted laser desorption and electrospray: Current status. Anal. Biochem. 230: 205-214.

76. Muddiman, D.C., Wunschel, D.S., Liu, C., Pasa-Tolic, L., Fox, K.F., Fox, A., Anderson, G.A. and Smith, R.D. 1996. Characterization of PCR products from Bacilli using electrospray ionization FTICR mass spectrometry. Anal. Chem. 68: 3705-3712.

77. Roskey, M.T., Juhasz, P., Smirnov, I.P., Takach, E.J., Martin, S.A. and Haff, L.A. 1996. DNA sequencing by delayed extraction-matrix-assisted laser desorption/ ionization time of flight mass spectrometry. Proc. Natl. Acad. Sci. USA. 93: 4724-4729.

78. Krishnamurthy, T., Ross, P.L. and Rajamani, U. 1996. Detection of pathogenic and non-pathogenic bacteria by matrix-assisted laser desorption/ionization time-offlight mass spectrometry. Rap. Comm. Mass Spec. 10: 883-888.

79. Hannis, J.C. and Muddiman, D.C. 1999. Characterization of a microdialysis approach to prepare polymerase chain reaction products for electrospray ionization mass spectrometry using online ultraviolet absorbance measurements and inductively coupled plasma-atomic emission spectroscopy. Rapid Commun. Mass Spectrom. 13: 323-330.

80. Belgrader, P. et al. 1998. Rapid pathogen detection using a microchip PCR array instrument. Clin. Chem. 44: 2191-2194

81. Northrup, M.A., Benett, B., Hadley, D., Landre, P., Lehew, S., Richards, J. and Stratton, P. 1998. A miniature analytical instrument for nucleic acids based on micromachined silicon reaction chambers. Anal. Chem. 70: 918-922.

82. Wilding, P., Shoffner, M.A. and Kricka, L.J. 1994. PCR in a silicon microstructure. Clin. Chem. 40: 1815-1818.

83. Swerdlow, H., Jones, B.J. and Wittwer, C.T. 1997. Fully automated DNA reaction and analysis in a fluidic capillary instrument. Anal. Chem. 69: 848-855.

84. Wittwer, C.T., Fillmore, G.C. and Hillyard, D.R. 1989. Automated polymerase chain reaction in capillary tubes with hot air. Nucl. Acids Res. 17: 4353-4357.

85. Woolley, A.T., Sensabaugh, G.F. and Mathies, R.A. 1997. High-speed DNA genotyping using microfabricated capillary array electrophoresis chips. Anal. Chem. 69: 2181-2186.

86. Henke, L., Piunno, P.A.E., McClure, A.C. and Krull, U.J. 1997. Covalent immobilization of single-stranded DNA onto optical fibers using various linkers. Anal. Chim. Acta. 344: 201-213.

87. Watts, H.J., Yeung, D. and Parkes, H. 1995. Real-time detection and quantification of DNA hybridization by an optical biosensor. Anal. Chem. 67: 4283-4289.

88. Ferguson, J.A., Boles, T.C., Adams, C.P. and Walt, D.R. 1996. A fiber-optic DNA biosensor microarray for the 
analysis of gene expression. Nature Biotechnol. 14: 1681-1684.

89. Jensen, K.K., Ørum, H., Nielsen, P.E. and Nordén, B. 1997. Kinetics for hybridization of peptide nucleic acids (PNA) with DNA and RNA studied with the BIAcore technique. Biochemistry. 36: 5072-5077.

90. Thiel, A.J., Frutos, A.G., Jordan, C.E., Corn, R.M. and Smith, L.M. 1997. In situ surface plasmon resonance imaging detection of DNA hybridization to oligonucleotide arrays on gold surfaces. Anal. Chem. 69: 4948-4956.

91. Little, D.P., Cornish, T.J., O’Donnell, M.J., Braun, A., Cotter, R.J. and Köster, H. 1997. MALDI on a chip: analysis of arrays of low-femtomole to subfemtomole quantities of synthetic oligonucleotides and DNA diagnostic products dispensed by a piezoelectric pipet. Anal. Chem. 69: 4540-4546.

92. Baselt, D.R., Lee, G.U., Natesan, M., Metzger, S.W., Sheehan, P.E. and Colton, R.J. 1998 A biosensor based on magnetoresistance technology. Biosens. Bioelectron. 13: 731-739.

93. Baselt, D.R., Lee, G.U. and Colton, R.J. 1996. A biosensor based on force microscope technology. J. Vac. Sci. Technol. B 14: 789-793.

94. Allen, S. et al. 1997. Detection of antigen-antibody binding events with the atomic force microscope. Biochemistry. 36: 7457-7463. 


\section{Further Reading}

Caister Academic Press is a leading academic publisher of advanced texts in microbiology, molecular biology and medical research. Full details of all our publications at caister.com

- MALDI-TOF Mass Spectrometry in Microbiology Edited by: M Kostrzewa, S Schubert (2016) www.caister.com/malditof

- Aspergillus and Penicillium in the Post-genomic Era Edited by: RP Vries, IB Gelber, MR Andersen (2016) www.caister.com/aspergillus2

- The Bacteriocins: Current Knowledge and Future Prospects Edited by: RL Dorit, SM Roy, MA Riley (2016)

www.caister.com/bacteriocins

- Omics in Plant Disease Resistance Edited by: V Bhadauria (2016) www.caister.com/opd

- Acidophiles: Life in Extremely Acidic Environments Edited by: R Quatrini, DB Johnson (2016) www.caister.com/acidophiles

- Climate Change and Microbial Ecology: Current Research and Future Trend

Edited by: J Marxsen (2016)

www.caister.com/climate

- Biofilms in Bioremediation: Current Research and Emerging Technologies

Edited by: G Lear (2016)

www.caister.com/biorem

- Microalgae: Current Research and Applications Edited by: MN Tsaloglou (2016) www.caister.com/microalgae

- Gas Plasma Sterilization in Microbiology: Theory, Applications, Pitfalls and New Perspectives Edited by: H Shintani, A Sakudo (2016) www.caister.com/gasplasma

- Virus Evolution: Current Research and Future Directions Edited by: SC Weaver, M Denison, M Roossinck, et al. (2016) www.caister.com/virusevol

- Arboviruses: Molecular Biology, Evolution and Control Edited by: N Vasilakis, DJ Gubler (2016) www.caister.com/arbo

- Shigella: Molecular and Cellular Biology Edited by: WD Picking, WL Picking (2016) www.caister.com/shigella

-Aquatic Biofilms: Ecology, Water Quality and Wastewater Treatment

Edited by: AM Romaní, H Guasch, MD Balaguer (2016)

www.caister.com/aquaticbiofilms

- Alphaviruses: Current Biology

Edited by: S Mahalingam, L Herrero, B Herring (2016)

www.caister.com/alpha

- Thermophilic Microorganisms

Edited by: F Li (2015)

www.caister.com/thermophile
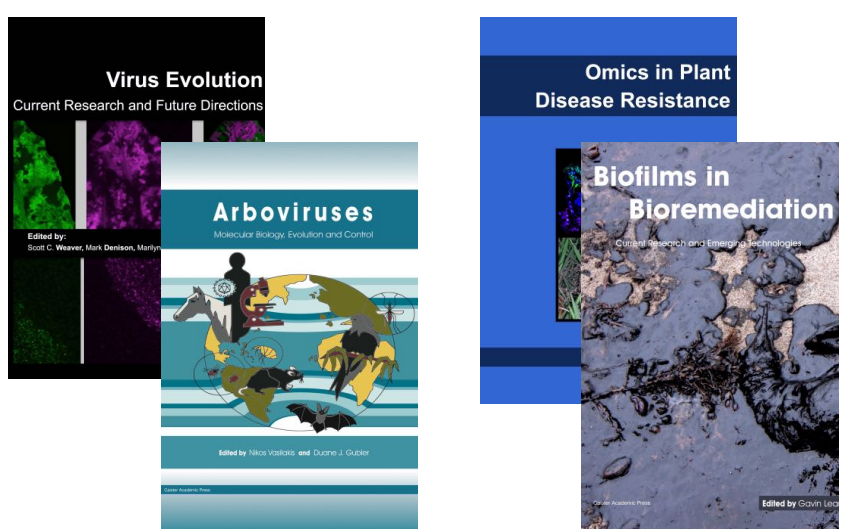
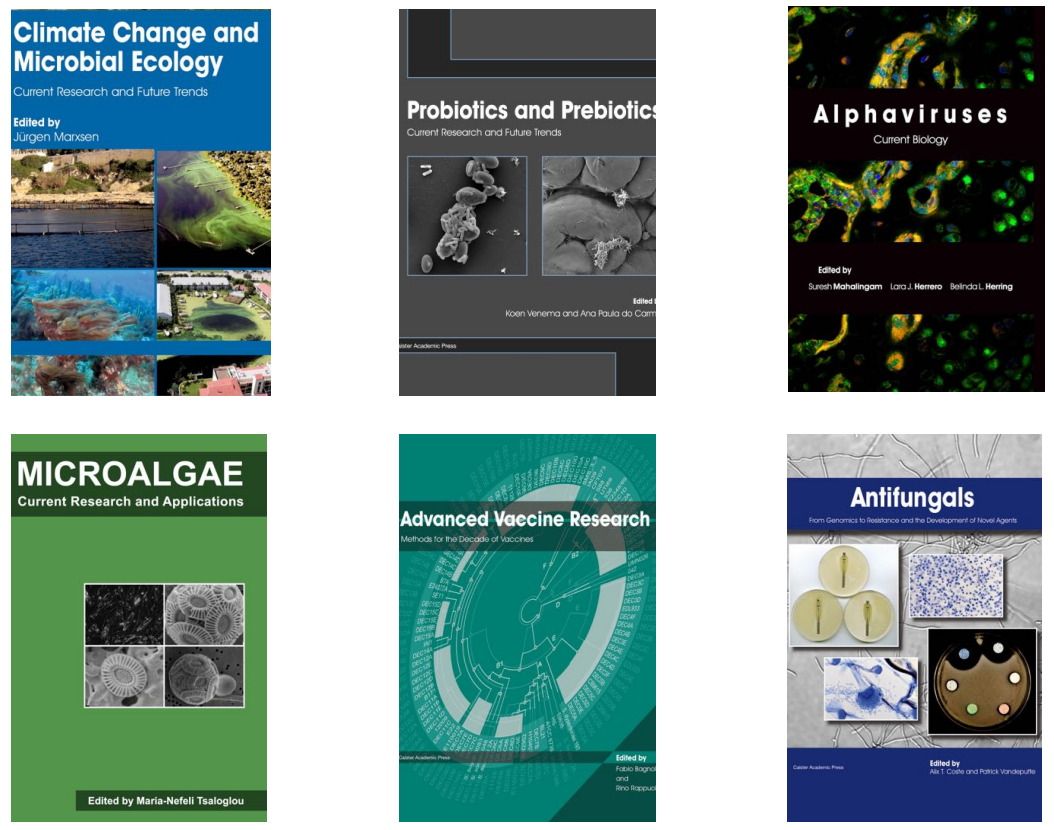

- Flow Cytometry in Microbiology: Technology and Applications Edited by: MG Wilkinson (2015) www.caister.com/flow

- Probiotics and Prebiotics: Current Research and Future Trends Edited by: K Venema, AP Carmo (2015) www.caister.com/probiotics

- Epigenetics: Current Research and Emerging Trends Edited by: BP Chadwick (2015) www.caister.com/epigenetics2015

- Corynebacterium glutamicum: From Systems Biology to Biotechnological Applications

Edited by: A Burkovski (2015)

www.caister.com/cory2

- Advanced Vaccine Research Methods for the Decade of Vaccines

Edited by: F Bagnoli, R Rappuoli (2015)

www.caister.com/vaccines

- Antifungals: From Genomics to Resistance and the Development of Novel Agents

Edited by: AT Coste, P Vandeputte (2015)

www.caister.com/antifungals

- Bacteria-Plant Interactions: Advanced Research and Future Trends Edited by: J Murillo, BA Vinatzer, RW Jackson, et al. (2015) www.caister.com/bacteria-plant

\section{- Aeromonas}

Edited by: J Graf (2015)

www.caister.com/aeromonas

- Antibiotics: Current Innovations and Future Trends

Edited by: S Sánchez, AL Demain (2015)

www.caister.com/antibiotics

- Leishmania: Current Biology and Contro Edited by: S Adak, R Datta (2015) www.caister.com/leish2

- Acanthamoeba: Biology and Pathogenesis (2nd edition) Author: NA Khan (2015)

www.caister.com/acanthamoeba2

- Microarrays: Current Technology, Innovations and Applications Edited by: Z He (2014)

www.caister.com/microarrays2

- Metagenomics of the Microbial Nitrogen Cycle: Theory, Methods and Applications

Edited by: D Marco (2014)

www.caister.com/n2 